研究ノート

\title{
管理型最終処分場が流域水循環に及ぼす 影響に関する基礎的研究
}

\author{
藤本 雄大 1） 田中基弘 2) 手計 太一 3) \\ 平野文昭 3) 松藤 康司 3)4)5) \\ 1)福岡大学大学院工学研究科建設工学専攻 \\ ( ₹814-0180 福岡市城南区七隈8-19-1) \\ 2)首都高速道路株式会社 \\ （１00-8930 千代田区霞が関1-4-1） \\ 3)福岡大学 工学部 社会デザイン工学科 \\ (テ814-0180 福岡市城南区七隈8-19-1) \\ 4)福岡大学大学院工学研究科資源循環 - 環境工学専攻 \\ (干814-0180 福岡市城南区七隈8-19-1) \\ 5)福岡大学 環境保全センター \\ (テ814-0180 福岡市城南区七噮8-19-1)
}

近年，森林破壊，灌溉面積の増加，ダム貯水池の建設，都市化などによって，河川水の質，量ともに，大きく変 化している.このような社会変動と水循環の相互作用の関係については未解明な部分が多い. その要因の一つとし て, 把握しきれていない人間活動の存在が挙げられる. 本研究では, 福岡県西部に位置する瑞梅寺川流域と福岡市 西部最終処分場を対象として, 管理型最終処分場が流域水循環に与える影響を明らかにするための基礎的な検討を 行った.

その結果, 最終処分場に因る水量の人為的な操作によって, 自然の河川流況に影響を与えていることを示唆した. また, 最終処分場への降雨が河川に戻る時間遅れは, 最終処分場の埋立地や污水処理場での滞留によって生じてい ることを明らかにした，特に大雨時や降雨が連続した場合において，最大放流量の緩和および河川への放流の時間 遅れが顕著であることを示した.

世界規模で廃棄物発生量は増加しており，一部の地域や国では最終処分場が巨大化している，そのため，最終処 分場が流域水循環へ与える影響の評価は今後も重要な検討課題と考えられる.

キーワード：最終処分場, 流域管理, 水循環, 人間活動, 福岡県

\section{I 、はじめに}

有史以来, 人類は河川近傍にコミュニティを形 成し, 社会や経済の中心に発展し, そして文明が 築かれてきた。人間が生存するために, 河川流域 は大きく開発され続けている。 その中で, 特に近 年, 森林破壊, 灌溉面積の増加, 夕゙ム貯水池の建 設，都市化などによって，河川水の質，量ともに， 大きく変化している。例えば，人間活動による淡 水資源の減少量の推計によると，1910年から 1990 年までの年平均值と1990年の值を比較すると最大 で約 1.5 倍の減少量であることが推定されている
(森澤，2003)。また，大規模ダム貯水池が河川流 況に与える影響（手計ら，2004）など, 大規模な 人間活動による水循環への影響を検討した研究は 数多く既出されている. しかし, 社会変動と水循 環の相互作用という問題については未解明な部分 が多いのが実情である。その理由の一つとして, 流域水循環に影響を及ぼすと考えられるものの, 把握しきれていない人間活動が存在するというこ とが挙げられる。

そこで本研究では, 準閉鎖系の水循環を持つと 考えられる管理型最終処分場が流域水循環に与え 
る影響を明らかにする。本稿における「準閉鎖系 の水循環」とは, 最終処分場の埋立地に降った雨 が地下へ浸透することなく，一部が蒸発し，その 他は集水され污水処理過程を経て河川に放流され るということを意味している，一般的に，最終処 分場は広大な土地を有しているため，人間活動要 因の一つであると言える.

これまでの最終処分場に打ける水問題は水質が 主であり（例えば，松藤ら，1997；土井ら，2004）， 水量についての議論はほとんどなされてこなかっ たのが実情である。しかし，上述のように，最終 処分場では，非常に特殊でかつ人為的に水循環が 変化していることは明らかである。近年の地球の 人口増加に伴い，廃棄物の増加が顕著になってお り，最終処分場の増加は避けることができない. 河川流域内に特殊な水循環を持つ領域が増加する ことは想像に難くない.

以上を鑑み，本稿では福岡県西部に位置する瑞 梅寺川流域と福岡市西部最終処分場を対象として, 管理型最終処分場が流域水循環に与える影響を明 らかにするための基礎的な検討を行った。

\section{II . 最終処分場}

世界各国で廃棄物対策が推進されている今日に おいても，廃棄物発生量は依然として増加傾向に
ある。1980年から2003年における OECD諸国の一般 廃棄物発生量の推移を図一1に示す (OECD, 2006). 1980年から 2003年に亘り一般廃棄物の発生量は増 加を示している。OECD諸国においては，世帯人員 数の減少, 豊かさや消費水準の上昇傾向などの社 会動向によって，さらに一般廃裹物が増加すると 推定されている (OECD環境局，2002）。また，ア ジア地域の発展途上国に抒いても，急速な都市化 に伴い廃棄物の発生量が増加するものと考えられ る（田中，2004）。

2004年度に扔ける我が国の一般廃棄物の発生量 は年間約 5000 万であり，その処理方法は78％が焼 却処分，18\%が堆肥化施設やメタン回収施設等の 資源化による中間処分，4\%が埋立処分されている (環境省，2006)。近年，最終処分場の用地確保が 困難になっていることから，埋立処分量の削減の ために我が国では焼却処分を行っている.

対象埋立廃裹物の種類によって最終処分場は, 安定型, 管理型, 遮断型の3つに分類される。本研 究で対象とした西部最終処分場は管理型最終処分 場である、管理型最終処分場は環境を污染する可 能性のある廃棄物等が埋立処分されるため水質, 水量ともに管理されている。 そのため, 流域水循 環に影響を与えていることが懸念される.

図一2は1978年から2004年における我が国の一般 廃棄物処分場数招よび廃棄物埋立可能容量 (各埋

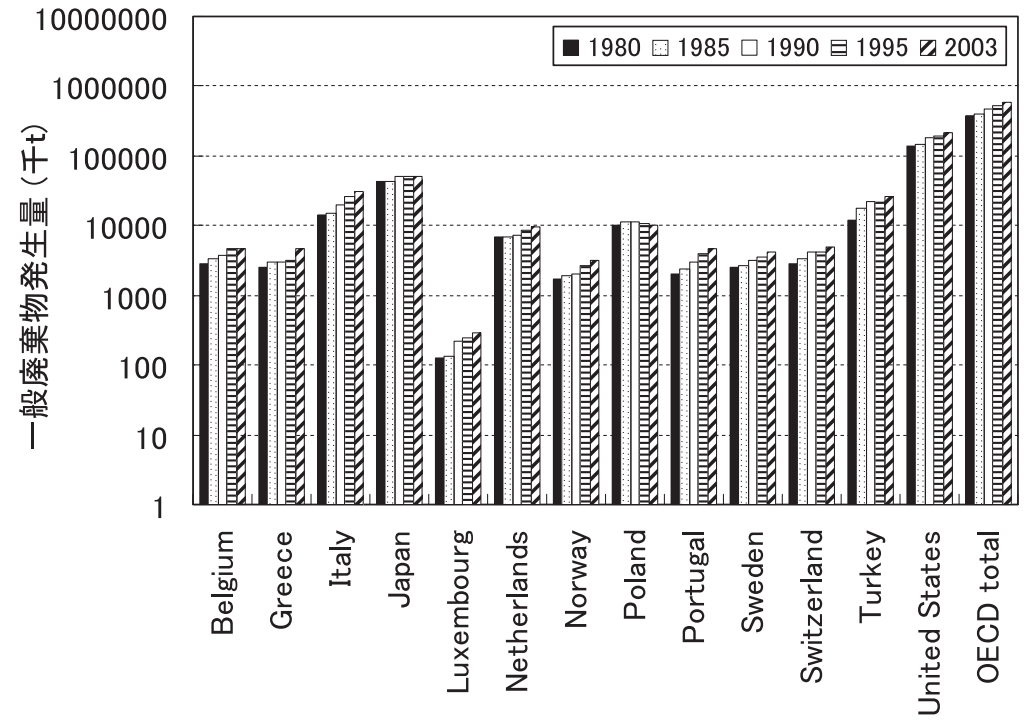

図－1 1980年から2003年に㧍けるOECD諸国の一般廃棄物発生量の推移（OECD，2006）.

Fig.1 Transition of municipal waste generation in OECDcountries during 1980-2003. 


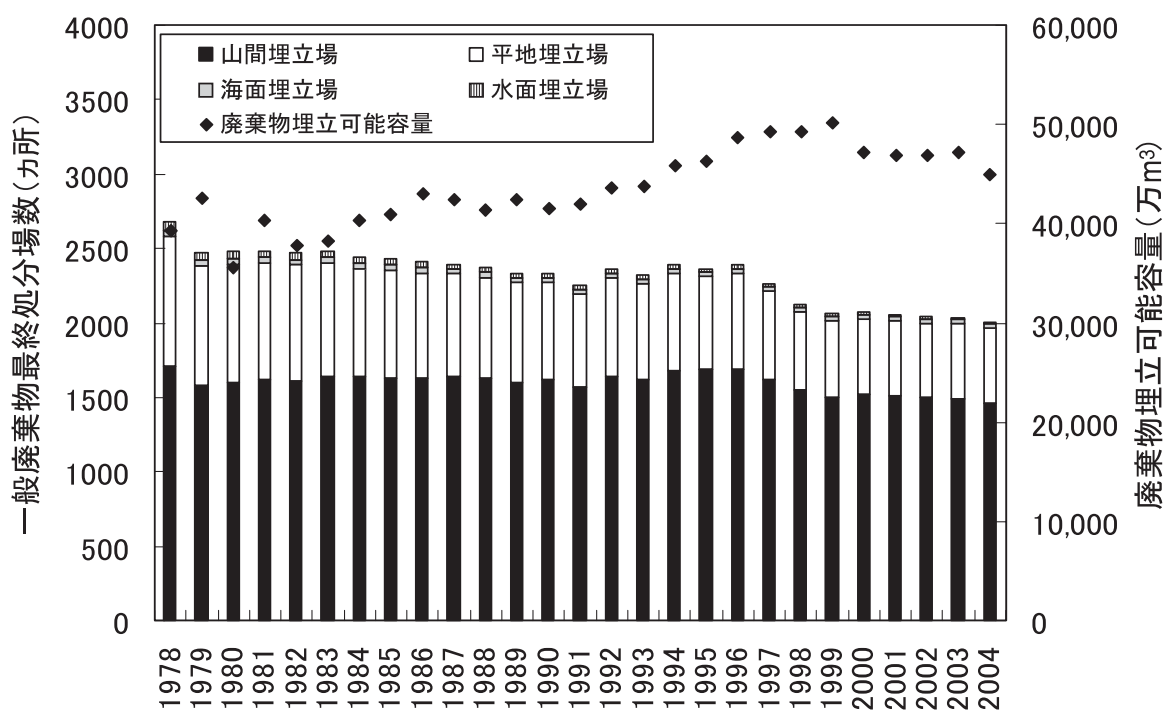

図－2 1978年から2004年における我が国の一般廃裹物処分場数㧍よび廃棄物埋立可能容量(各埋立地における埋立可 能容量の総和)の推移 (環境省, 2005 ; 環境省, 2006).

Fig.2 Transition of the number of sanitary landfill sites of municipal waste and filling in land capacity during 1978-2004.

立地に扔ける埋立可能容量の総和）の推移（環境 省，2005；環境省，2006）である。図一2より，近 年, 最終処分場数の減少傾向（廃止された最終処 分場は施設数から除外されている）にあるものの， 全体の廃裹物埋立可能容量が僅かに増加を示して いる。一箇所の最終処分場あたりの廃棄物埋立可 能容量に換算すると，例えば，1978年から1982年 までの 5 年間では約 16 万 $\mathrm{m}^{3}, 2000$ 年から 2004 年まで の5年間では約23万 $\mathrm{m}^{3}$ である。このことから，1978 年から1982年までの一箇所あたりの廃棄物埋立可 能容量に比べて，2000年から2004年までの一箇所 あたりの廃衰物埋立可能容量は約1.4倍で，増大し ている。また，2004年の最終処分場の立地は，山 間埋立場 $73 \%$ ，平地埋立場 $25 \%$ ，海面および水面 埋立場 $2 \%$ あ゙る。従って，我が国の最終処分場は 山間部と平地で $98 \%$ を占めており，日本全国に幅 広く埋立場が存在していると言える。

一方，諸外国の廃棄物処理の事例を挙げると， 例えば，一般廃棄物排出量が世界で最も多いアメ リカでは，一般廃棄物総排出量（年間約 2 億 $\mathrm{t}$ ) の5 割以上が埋立処分されており, 廃棄物埋立容量 100 万t以上の大規模な最終処分場が建設されている (田中, 2004).

\section{III。研究対象とした流域と最終処分場}

\section{1. 研究対象流域}

本研究において対象としたのは, 福岡県西部を 流れる瑞梅寺川流域である。流域面積は $52.6 \mathrm{~km}^{2}$, 幹川延長は $13.2 \mathrm{~km}$ の二級河川である. 年平均降水 量は約 $1600 \mathrm{~mm}$ ，年流出高は約 $750 \mathrm{~mm}$ である。流 域の土地利用は, 宅地 $10 \%$, 農耕地 $33 \%$, 山林 . 原野 $45 \%$ ，その他 $12 \%$ となっており，流域は細長 く, 平均河床勾配が上流では約 $1 / 100$, 下流では約 $1 / 350$ と急峻な河川であるため洪水流出は早く, 河 道は狭小なため流下能力が低い（福岡県，2003）。

\section{2. 研究対象とした最終処分場}

研究対象とした最終処分場は, 福岡市の西部 （中田）埋立場，西部（今津）埋立場㧍よび西部污 水処理場である(本稿ではそれぞれ,「中田埋立場」, 「今津埋立場」および「污水処理場」とする).

中田埋立場は, 主に福岡市内の清掃工場からの 焼却灰や, 破砕物等を埋立処分している山間埋立 場である。中田埋立場から発生する浸出水は約 $3.5 \mathrm{~km}$ 離れた污水処理場で処理されている。埋立期 間は 1996 年 4 月から約 20 年間, 埋立面積は約 18 万 $\mathrm{m}^{2}$ (全国順位第32番目，2004年現在), 埋立容量は約 183.3 万 $\mathrm{m}^{3}$ (全国順位第37番目，2004年現在）を予 定している。日本の一般廃衰物最終処分場の2009 施設（2004年現在）の平均埋立面積は約 2.4 万 $\mathrm{m}^{2}$, 
平均埋立容量は約 22 万 $\mathrm{m}^{3}$ あ゙あり, 中田埋立場の埋 立面積と埋立容量は全国平均より8倍程度の規模で ある(環境省，2006）。

今津埋立場は1975年2月に埋め立てを開始し，家 庭系一般廃棄物，焼却灰および破砕物等を埋立処分 し，1999年9月に埋め立てを終了した平地埋立場で ある。埋立面積は 64.4 万 $\mathrm{m}^{2}$, 埋立容量は 168.7 万 $\mathrm{m}^{3}$ である，埋立終了後，運動公園や農園などに跡地利 用されているが，現在でも周辺環境への影響を考慮 して浸出水を処理している。 その浸出水は污水処理 場で処理されている。

污水処理場は，今津埋立場の供用開始にあわせ て建設された污水処理施設で, 生物処理に加えて 凝集沈殿, 砂万過, 活性炭吸着の高度処理を行っ ている。また，定格処理能力（以下，「処理能力」 とする）は $2800 \mathrm{~m}^{3} /$ 日である。中田埋立場と今津埋 立場の浸出水を排水基準以下の水質まで処理し, 瑞梅寺川の河口付近へ放流している.

ここで，最終処分場に扔ける水循環について詳 述する．最終処分場の埋立地への降水は，埋立地 の廃棄物層内の様々な污濁物質を含み有害な污水 （以下，「浸出水」とする）となって流出する。こ の浸出水は浸出水調整槽に一時貯留され, 污水処 理施設に送られた後，排水基準以下の水質まで処 理され河川等へ放流される。この浸出水によって 土壤や地下水, 放流先の公共水域が污染されない ようにするため, 我が国の一般廃棄物最終処分場は, 浸出水処理施設との併設および最終処分場の埋立地 底部に遮水シートや不透水性地層などの遮水工を設 けることが法律によって義務づけられている（財団 法人日本産業廃妄物処理振興センター, 2002)。

福岡市西部最終処分場に扔ける浸出水処理フロー の概略図を図一3に示す。中田埋立場においても， 浸出水集排水施設の底部には浸出水による漏水防
止のために遮水シートが敷設されている。そのた め, 埋立地に降った降水は廃棄物層への浸透や豎 型ガス抜き管に流入した後，埋立地底部に敷設し てある浸出水集排水管に集水され，堤内貯留池を 経由し, 浸出水調整槽へ送られる。また, 中田埋 立場では浸出水調整槽の水位を一時間ごとに自動 計測し，その水位が $1.5 \mathrm{~m}$ 以上にならないように浸 出水調整槽の水位の調整を行っている. 中田埋立 場に打いては，埋立地底部の遮水シートに負荷を かけないようにできるかぎり堤内貯留施設での貯 留を行わないことを前提としているため, 発生す る浸出水量を一般的な天気予報などから予測して, 中田埋立場の浸出水調整槽から污水処理場へポン プ圧送する浸出水量を決定している.

污水処理場では中田埋立場と今津埋立場から圧 送された浸出水を污水受水槽で混合し, 処理施設 に扔いて処理した後，瑞梅寺川に放流している。 また, 必要に応じて污水受水層の浸出水は, 浸出 水調整池貯留へ送られ一時的に貯留される.

\section{3. データ}

中田埋立場では, 浸出水量は直接計測されてい ないため, 本研究では, 以下に示す方法により算 出した浸出水量を「実質浸出水量」と定義する.

$$
\begin{aligned}
& Q_{(i)}=\Delta Q_{1}+\Delta Q_{2}+Q_{3} \\
& \Delta Q_{1}=\frac{V_{a(i)}-V_{a(i-1)}}{\Delta t} \\
& \Delta Q_{2}=\frac{V_{b(i)}-V_{b(i-1)}}{\Delta t} \\
& Q_{3}=Q_{s(i)}
\end{aligned}
$$

ここで, $Q_{(i)}$ は $i$ 日に扔ける実質浸出水量 $\left(\mathrm{m}^{3} /\right.$ 日),$\Delta$ $Q_{1}$ は堤内貯留施設の浸出水変化量 $\left(\mathrm{m}^{3} /\right.$ 日),$\Delta Q_{2}$ は

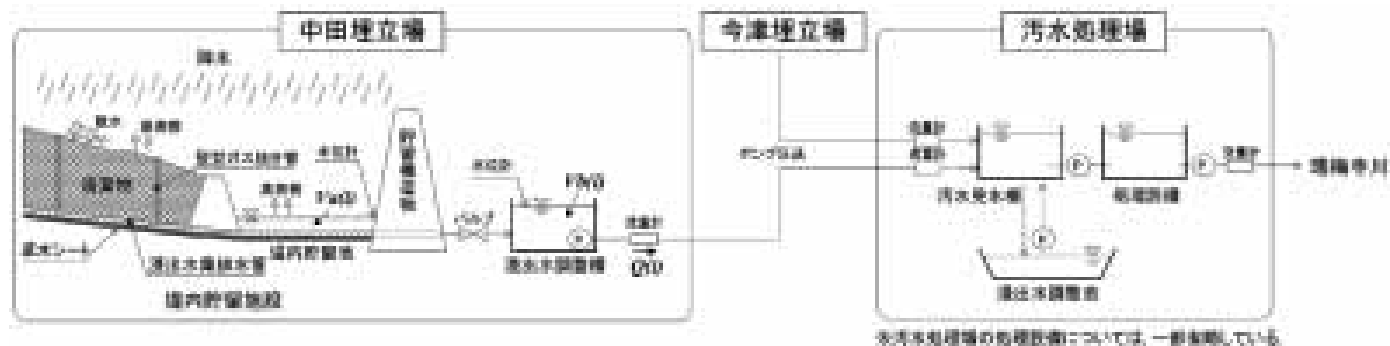

図－3 福岡市西部最終処分場における浸出水処理フローの概略図.

Fig.3 Schematic of leachate treatment process in Fukuoka Seibu landfill system. 
浸出水調整槽の浸出水変化量 $\left(\mathrm{m}^{3} /\right.$ 日), $Q_{3}\left(Q_{s(i)}\right)$ は $i$ 日に扔ける送水した浸出水量 $\left(\mathrm{m}^{3} /\right.$ 日),$V_{a(i)}\left(V_{b(i)}\right)$ は $i$ 日に扮ける堤内貯留施設 (浸出水調整槽) の貯留 浸出水量 $\left(\mathrm{m}^{3}\right), \Delta t$ は, 1 日である.

最終処分場の集水面積は埋立の進行に伴い変化 するため，埋立状況に応じた集水面積が必要とな る。そこで，福岡市が測定した1999年から2002年 までの埋立場測量デー夕をもとに集水面積を算出 した。図一3のように，中田埋立場と今津埋立場か らの浸出水は污水処理場へ送水される。両埋立場 から送られてくる浸出水量の和を本稿では「流入 量」, 污水処理場から瑞梅寺川への放流量を「放流 量」と定義した。

\section{IV．中田埋立場に招ける雨水浸透解析}

中田埋立場では廃裹物の飛散防止, 道路の清掃 を目的として散水を行っている.1日に平均7回行 うこととなっているが，その内，浸出水量へ影響 を与える埋立地への散水の回数は特に決まってお らず，そのデー夕は蓄積されていない。そのため, 本稿では，埋立地内へ1日に7回の散水を行ったと 仮定した水量を「散水量」，中田埋立場の降雨量に 散水量を加えた水量を「実質最大降雨量」と定義 した。

図一4は1999年から2002年に扔ける西部（中田） 埋立場の月降雨量と月実質浸出水量の関係（エラー バーの上限值は実質最大降雨量 (降雨量十散水量), 下限值は降雨量を示す）である。全体的に，実質 浸出水量が降雨量より過小となっている。その要 因として，堤内貯留池では植物が生えていること や，堤内貯留池に集まった浸出水は大気と直接接 しているため, 堤内貯留池での蒸発散損失が考え られる。さらに，大雨が降った時には埋立場の表 面に雨水が貯まるので蒸発損失が考えられる.

最終処分場埋立地の鉛直構造が一般的な土壤と 異なる点として，廃裹物埋立による廃裹物層厚の 変化や，竪型ガス抜き管および浸出水集排水管， 遮水シートの設置などが挙げられる。また，管理 型最終処分場では焼却灰や破砕物等が埋め立てら れていることから，埋立地組成に関しても一般土 壤と大きく異なる。そこで, 最終処分場の埋立地 ではどのような要因が降雨一流出関係に影響を与 えているのかを明らかにするために, 本研究では, 次式を用いて浸出率を算定した（水文学での流出

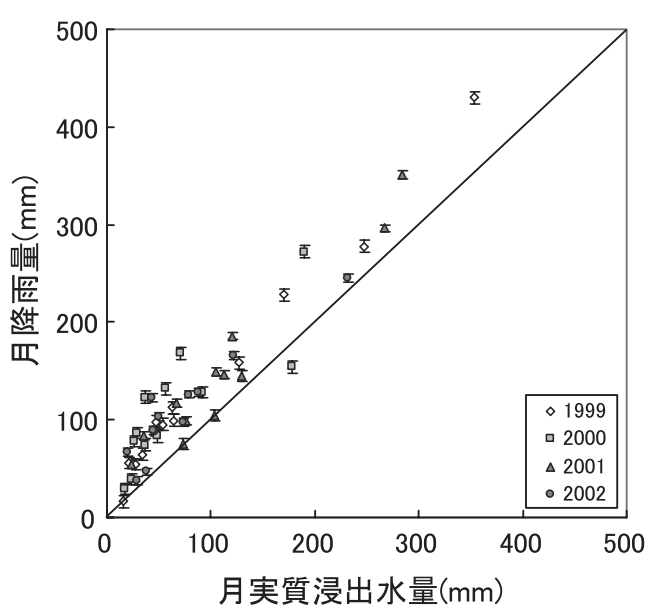

図－4 1999年から2002年における西部 (中田)埋立場の 月降雨量と月実質浸出水量の関係 (エラーバーの 上限值は実質最大降雨量 (降雨量十散水量), 下 限值は降雨量を示す).

Fig.4 Relationship between monthly rainfall and monthly estimated leachate discharge in Seibu (Nakata) landfill site during 1999-2002 (Upper limit of error bar is rainfall including sprinkling water in landfill site, lower limit of error bar is rainfall).

率と同義であり，廃棄物工学では浸出率と定義さ れている).

$$
C=\frac{1000 Q}{I \times A}
$$

ここで, $Q$ は実質浸出水量 $\left(\mathrm{m}^{3}\right), C$ は浸出率 $(\%), I$ は実質最大降雨量（降雨量十散水量）もしくは降雨量 $(\mathrm{mm}), A$ は集水面積 $\left(\mathrm{m}^{2}\right)$ である。（5）式からわか るように, 浸出率は実質最大降雨量および降雨量に対 する浸出水量の割合を表している.

1999年から2002年に扔ける西部（中田）埋立場 の月降雨量と月実質最大降雨量 (降雨量十散水量), これら両者により算出した月浸出率拉よび月浸出 水量の時系列を図一 5 に示す。降雨量と月実質最 大降雨量 (降雨量十散水量) および浸出水量の挙 動は良く一致している。しかし, 月浸出率の偏差 は大きく, 月降雨量のそれとは一致していない. 特に，2000年11月は月浸出率が100％を超えている が，これは浸出水の時間遅れがあるため，1２ヶ 月前の浸出水の影響を受けていることが考えられ る. 中田埋立場では浸出水量の削減のために, 埋 立地を区画分けして，順に埋立を行う区画埋立方 法が採用されている。2001年4月から第二区画の埋 立が開始されているが，図一5からは区画埋立方法 


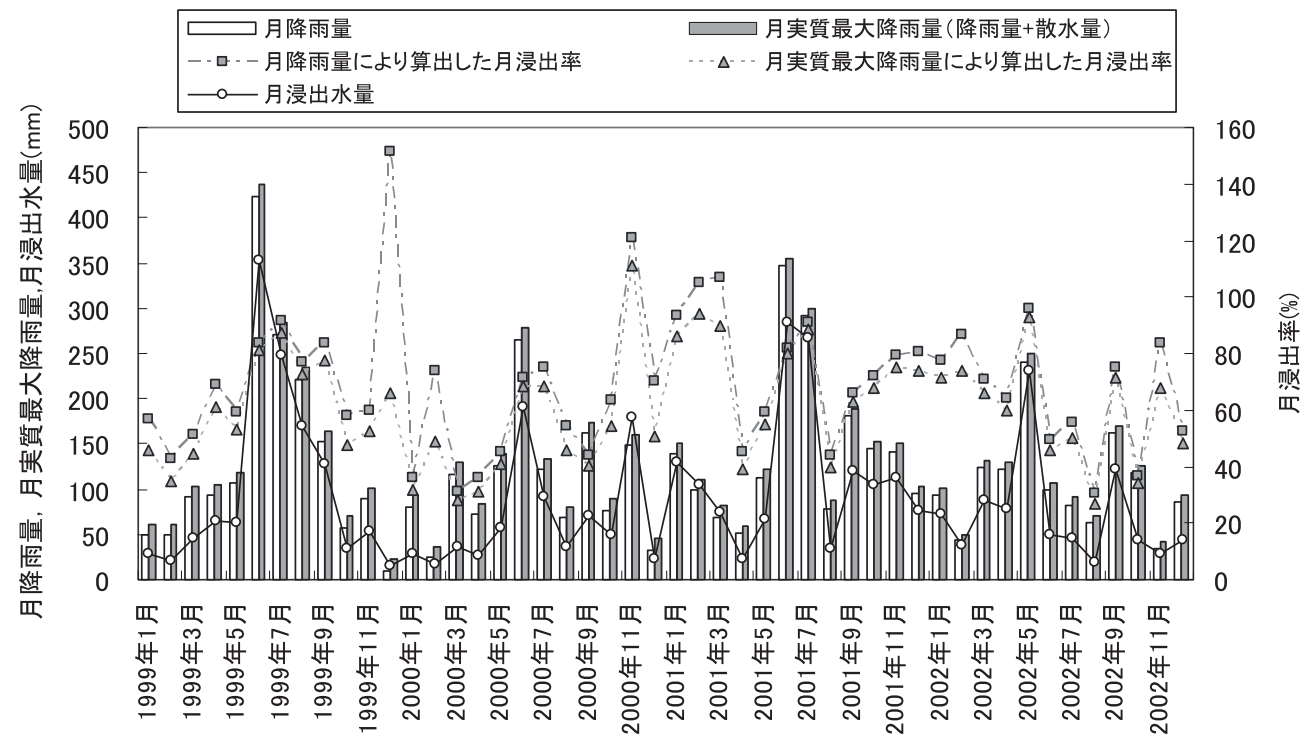

図－5 1999年から2002年における西部（中田）埋立場の月降雨量と月実質最大降雨量 (降雨量十散水量)，己れら 両者により算出した月浸出率および月浸出水量の時系列.

Fig.5 Time series of monthly rainfall, estimated maximum rainfall, leachate ratio and leachate discharge in Seibu (Nakata) landfill site during 1999-2002.

による月浸出率への大きな影響は認められない. また，月浸出率の変動幅が大きい。この要因とし て, 以下に挙げる最終処分場埋立地構造の複雑性 が考えられる。

第一に中田埋立場のごみを最大乾燥密度で締め 固めた透水係数は約 $3.8 \times 10^{-4} \mathrm{~cm} / \mathrm{s}$ であり（西村ら， 2000)，さらに焼却灰には自硬性がある。第二に処

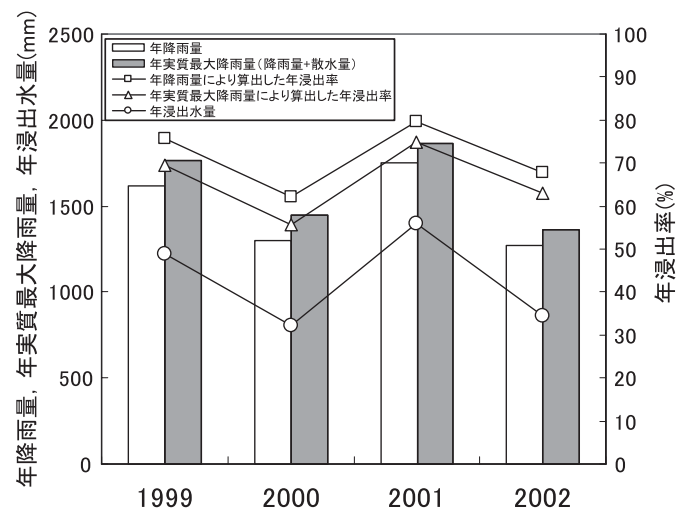

図－6 1999年から2002年における西部（中田）埋立場 の年降雨量と年実質最大降雨量（降雨量十散水 量), これら両者により算出した年浸出率および 年浸出水量の経年変化.

Fig.6 Annual change in rainfall, estimated maximum rainfall, leachate ratio and leachate discharge in Seibu (Nakata) landfill site during 1999-2002.
分場層内が多様な廃棄物や覆土層から成り立ってい る。第三に埋立地表面に流出した雨水を，埋立地表 面にある竪型ガス抜き管から, 直接, 浸出水集排水 管へ流入するように埋立作業を行っている. 上述し た埋立地構造の複雑性は, 月浸出率の有意な経年傾 向が検出されなかった1つの要因にもなる.

次に，1999年から2002年における西部（中田） 埋立場の年降雨量と年実質最大降雨量（降雨量十 散水量), これら両者により算出した年浸出率およ び年浸出水量の経年変化を図一6に示す。1999年か ら2000年までに浸出率は約 $14 \%$ 減少し，2000年か ら2001年までに浸出率は約 $14 \%$ 増加し，2001年か ら2002年までに浸出率は約 8 \% 減少している。この ように年浸出率が降雨量の挙動と同じょうに大き く増減している。

\section{$V$ ．福岡市西部最終処分場に扣ける水循環}

\section{1. 中田埋立場における降雨量と污水処理場にお ける流入量および放流量}

1999年から2002年における西部（中田）埋立場 の日降雨量, 西部污水処理場への日流入量および 西部污水処理場からの日放流量の時系列を図一7に 示す. 図中の破線は, 污水処理場の処理能力 $\left(2800 \mathrm{~m}^{3}\right.$ /日) を示している. 


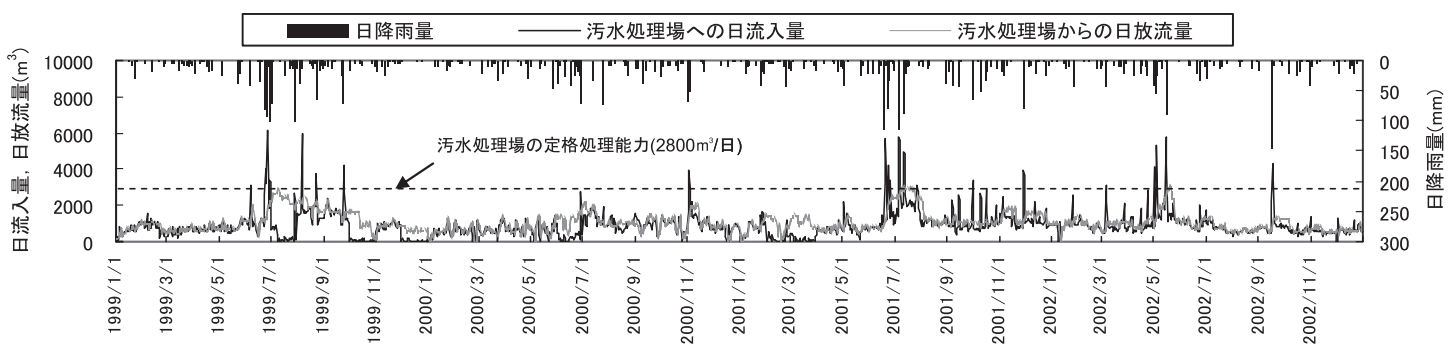

図－7 1999年から2002年における西部（中田）埋立場の日降雨量, 西部污水処理場への日流入量および西部污水処 理場からの日放流量の時系列.

Fig.7 Time series of daily rainfall, daily inflow discharge to Seibu leachate treatment plant and daily outflow discharge from Seibu leachate treatment plant in Seibu (Nakata) landfill site during 1999-2002.

中田埋立場の日降雨量と污水処理場への日流入 量および污水処理場からの日放流量の関係に着目 すると，降雨量が少ない場合では流入量と放流量 は同様の挙動を示しているが，降雨量が多い場合 では流入量と放流量の差は大きい。これは，污水 受水槽への流入量が多くなり処理設備への流入量 が処理能力を超えると予測され, 污水受水槽もし くは浸出水調整池において貯留が行われたためで ある。

次に，污水処理場に流入した浸出水が，最終的 にどのような要因で時間遅れを生じているのかを明 らかにするため，図一7の一部を拡大した。図一8， 図一9はそれぞれ図ー7における2002年7月から12月 までの6ケ月間，2000年7月から 12 月までの6ケ月間 を拡大した図である。図一8に着目すると，2002年 9月16日に記録した日降雨量 $(145 \mathrm{~mm})$ に対応する

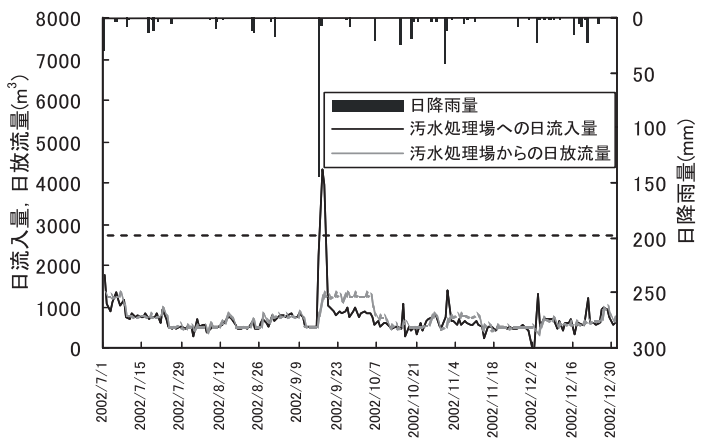

図－8 2002年7月から2002年12月における西部（中田） 埋立場の日降雨量, 西部污水処理場への日流入量 および西部污水処理場からの日放流量の時系列.

Fig.8 Time series of daily rainfall, daily inflow discharge to Seibu leachate treatment plant and daily outflow discharge from Seibu leachate treatment plant in Seibu (Nakata) landfill site during July to December 2002.
污水処理場への流入量のピークは，1日遅れて現れ ている。その後，降雨が無いにも関わらず約 $1300 \mathrm{~m}^{3}$ /日の放流量が一定して続いている。これは, 9月 17 日の日流入量が処理能力 $\left(2800 \mathrm{~m}^{3} /\right.$ 日) を超 えていることからわかるように，流入量の一部が浸 出水調整池に貯留されているためである。9月16日 の前後には大きな降雨はなく, 日流入量が処理能力 (2800 m³) を超えてないことから, 浸出水調整 池への貯留は9月15日以前には行われていないと推 測できる。そのため，多量の放流量を維持している 2002年9月17日から2002年10月4日までの18日間は, 浸出水貯留池に貯留を行っていた期間と推察でき る。つまり，この18日間の放流量は，2002年9月 16 日の降雨による放流量であると言える。

同様の傾向として，図－9に示した2000年11月 1 日から2日までの降雨量とその直後の放流量の関係

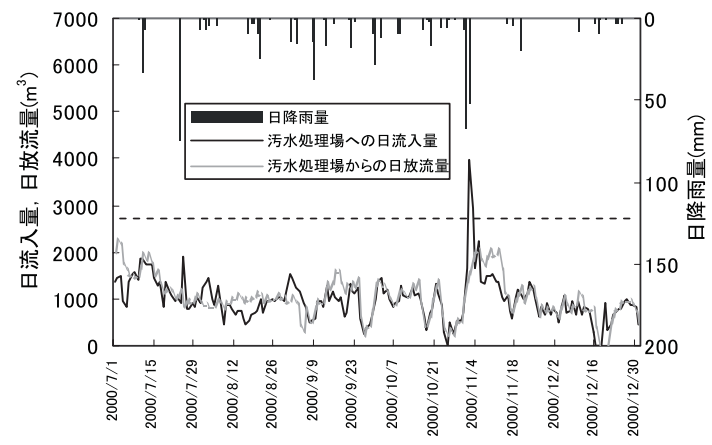

図－9 2000年7月から2000年12月における西部（中田） 埋立場の日降雨量, 西部污水処理場への日流入 量および西部污水処理場から日放流量の時系列.

Fig.9 Time series of daily rainfall, daily inflow discharge to Seibu leachate treatment plant and daily outflow discharge from Seibu leachate treatment plant in Seibu (Nakata) landfill site during July to December 2000. 
が挙げられる。11月1日における降雨の翌日に流入 量が処理能力 $\left(2800 \mathrm{~m}^{3} /\right.$ 日) を超えているため, 浸 出水を浸出水貯留池に貯留していると推定できる. 多量の放流量を維持している2000年11月2日から 2000年11月14日までの14日間の放流量は，2000年 11月1日から2日までの降雨による放流量と言える。

また，2002年9月16日に記録した降雨量 $145 \mathrm{~mm} /$ 日のイベントに着目すると, 同日の直後では污水 処理場への流入量のピークは9月 17 日に $4335 \mathrm{~m}^{3}$ /日 を記録して扮り，同日以降18日間の放流量に着目 すると約 $1300 \mathrm{~m}^{3} /$ 日を一定して放流している．最大 放流量は最大流入量に対して約 $70 \%\left(\right.$ 約 $3035 \mathrm{~m}^{3} /$ 日) 削減されている。

以上のことから，流入量の最大值に対し，放流 量の最大值は大幅に減少している。最終処分場に は，最大流入量に対する最大放流量の緩和と言う 視点から，ダム貯水池に類似したような機能を有 していると言える。

\section{2. 管理型最終処分場が河川流況に与える影響}

管理型最終処分場が河川流況に与える影響を明 らかにするために, 污水処理場からの処理水が放 流されている瑞梅寺川流域の平水流量と污水処理 場からの放流量を比較，検討した.

瑞梅寺川の流域面積に対する, 中田埋立場と今 津埋立場の合計集水面積の占める割合は約 $1 \%$ であ る. 瑞梅寺川の平水流量は約 11 万 $\mathrm{m}^{3} /$ 日（福岡市保 健環境研究所, 2003), 污水処理場に招ける4年間 の平均日放流量は約 $1000 \mathrm{~m}^{3}$ であり，これは平水流 量に対して約 $1 \%$ の流量である. 前述のように中田 埋立場から流出する浸出水は約 $3.5 \mathrm{~km}$ 離れた污水処 理場へ送水されており, その処理水は流域外であ る瑞梅寺川に放流している。 そのため, 中田埋立 場への降水量に対する浸出水量分（正確には処理 水量分), 瑞梅寺川の河川水量を増加させていると 言える。逆に，中田埋立場の位置する流域に扔い ては河川流量を減少させていると言える。

\section{VI.まとめ}

本研究では, 瑞梅寺川流域を対象として1999年 から2002年までの降雨量, 日流入量, 日放流量抒 よび推定した日浸出水量を利用して，管理型最終 処分場が流域水循環に与える影響について基礎的 な検討を行った。
その結果，最終処分場の埋立地に降った雨は, 浸出水調整槽, 污水受水槽, 浸出水調整池㧍よび 堤内貯留施設の貯留による水量の人為的な操作に より，自然の河川流況に影響を与えることを示唆 した。また，降雨が河川に戻る時間遅れは，最終 処分場の埋立地や污水処理場での滞留によって生 じていることを明らかにした，特に，大雨時や降 雨が連続した場合に扔いて, 最大放流量の緩和お よび河川への時間遅れが顕著であることを示した。

さらに, 中田埋立場を対象とした雨水浸透解析 を行った結果, 埋立地の鉛直構造は複雑であり, また，年浸出率は降雨量の影響を強く受けること を示した。

最後に, 我が国では埋立終了後も埋立地から流 出する浸出水を処理している最終処分場が多数存 在する。また, 浸出水が流域を越境している可能 性や，最終処分場の数は山間埋立場が最も多いこ とから，処理水が河川上流域に放流されている可 能性を鑑みると，流域水循環に大きな影響を与え ていると言える。さらに，現在，世界規模で廃棄 物発生量は増加しており, 一部の地域や国では最 終処分場が巨大化している。 そのため, 本研究で 明らかとなった最終処分場による流域水循環への 影響評価は今後も重要な検討課題である。

\section{謝辞}

本研究の遂行に際し, 福岡市, 大成管理開発株 式会社, 九州クリーン工業株式会社から貴重なデー タや情報を提供していただきました。ここに記し て謝意を表します。

\section{参考文献}

土井麻紀子・深津和彦・篠原亮太・花嶋正孝 - 桶口壯太郎・友田 啓二郎 (2004): 廃棄物埋立地浸出水の短期曝露によるヒメダ カ(Oryzias latipes)への影響, 廃棄物学会誌, 15 (4), pp.294301.

福岡県 (2003) : 瑞梅寺川水系河川整備基本方針.

福岡市保健環境研究所 (2003): 福岡市保健環境研究所報, 28, $17 \mathrm{pp}$.

環境省 (2005)：環境統計集 (平成17年版), ぎょうせい, $61 p p$.

環境省 (2006): 廃棄物処理技術情報, 平成16年度一般廃棄物処 理実態調査結果. http://www.env.go.jp/recycle/waste_tech/ippan/ h16/index.html

松藤康司・島岡隆行 (1997): 浸出水流出特性と埋立地建設への 課題, 廃棄物学会誌, 8(7), pp.510-522.

森澤眞輔 (2003) : 地球水資源の管理技術, コロナ社, 274pp.

西村義之 - 宮田克美 - 朴升鐸 - 持田悦夫 - 鈴木正人 - 加藤裕 (2000): 現場密度調査による効率的な埋立工法の考察, 廃棄 物学会研究発表会講演論文集, 11, pp.1175-1177.

OECD環境局 (2002)：OECD世界環境白書一2020年の展望, 中 
央経済社, pp.342-343.

OECD. 2006. OECD Fact book 2006:152-153.

田中勝 (2004): 日本と海外のごみ処理技術, 月刊廃棄物, 30

(10), pp.50-56.

手計太一・吉谷純一(2004): 大ダム建設が流況に与えた影響一
タイ王国・Chao Phraya川流域を対象として一, 水文・水資源 学会誌, 18, pp.281-292.

財団法人日本産業廃棄物処理振興センター(2002): 廃棄物の処

理及び清掃に関する法律関係法令集, ぎょうせい, pp.573-580.

(受付：2007年1月23日，受理：2007年8月3日)

\title{
Fundamental Study on the Effect of Controlled Landfill System on Hydrological Cycle in a Watershed
}

\author{
Yudai FUJIMOTO ${ }^{1)}$ Motohiro TANAKA ${ }^{2)}$ Taichi TEBAKARI ${ }^{3)}$ \\ Fumiaki HIRANO ${ }^{3)}$ Yasushi MATSUFUJI ${ }^{3 \text { ) 4)5) }}$ \\ 1) Graduate School of Architecture and Civil Engineering, Fukuoka University \\ (Nanakuma 8-19-1, Jounan, Fukuoka 814-0180, Japan) \\ 2) Metropolitan Expressway Company Limited \\ (Kasumigaseki 1-4-1, Chiyoda-ku, Tokyo 100-8930, Japan) \\ 3) Department of Civil Engineering, Fukuoka University \\ (Nanakuma 8-19-1, Jounan, Fukuoka 814-0180, Japan) \\ 4) Graduate School of Recycling and Eco-Technology, Fukuoka University \\ (Nanakuma 8-19-1, Jounan, Fukuoka 814-0180, Japan) \\ 5) Environment Protection Center, Fukuoka University \\ (Nanakuma 8-19-1, Jounan, Fukuoka 814-0180, Japan)
}

Human activities such as urbanization, reservoir development and deforestation affect on the watershed hydrological circulation. The purpose of this study is to clarify the impact of controlled landfill system on the watershed hydrological circulation. In this paper, the Seibu landfill system and the Zuibaiji River basin in Fukuoka prefecture was selected for this study.

As a result, we observed that outflow rate of leachte treatment plant was fairly constant independent of precipitation variation. Moreover, we estimated the rain-runoff mechanism at Fukuoka Seibu (Nakata) landfill site. We suggest that the controlled landfill system is going to affect on the watershed hydrological circulation in the near future.

Key words : sanitary landfill system, watershed management, hydrological cycle, human activities, Fukuoka prefecture 